\title{
Removal of toxic metals from solution by leaf, stem and root phytomass of Quercus ilex L. (holly oak)
}

\author{
M.N.V. Prasad ${ }^{*}, 1$, H. Freitas \\ Departamento de Botânica, Faculdade de Ciências e Tecnologia, Universidade de Coimbra, 3000 Coimbra, Portugal
}

Received 22 February 1999; accepted 2 November 1999

"Capsule": Holly oak phytomass was useful as a biofilter of toxic trace metals.

\begin{abstract}
Increased consciousness for safeguarding the aqueous environment has prompted a search for alternative technologies for the removal of toxic metal ions from aqueous solutions. In this regard, a wide variety of biomass is being considered as adsorbents of heavy metals for treatment of industrial and domestic wastewaters as well as natural waters, including drinking water. In the present investigation, the potential of Quercus ilex phytomass from stem, leaf and root as an adsorbent of chromium (Cr), nickel (Ni), copper $(\mathrm{Cu})$, cadmium $(\mathrm{Cd})$ and lead $(\mathrm{Pb})$ at ambient temperature was investigated. The metal uptake capacity of the root for different metals was found to be in the order: $\mathrm{Ni}>\mathrm{Cd}>\mathrm{Pb}>\mathrm{Cu}>\mathrm{Cr}$; stem $\mathrm{Ni}>\mathrm{Pb}>\mathrm{Cu}>\mathrm{Cd}>\mathrm{Cr}$; and leaf $\mathrm{Ni}>\mathrm{Cd}>\mathrm{Cu}>\mathrm{Pb}>\mathrm{Cr}$. The highest amount adsorbed was Ni (root $>$ leaf $>$ stem). Data from this laboratory demonstrated that Ni is sequestered mostly in the roots, where concentrations can be as high as $428.4 \mathrm{ng} / \mathrm{g}$ dry wt., when 1-year-old seedlings were treated with $\mathrm{Ni}$ (2000 $\mathrm{mg} / \mathrm{l})$ in pot culture experiments, compared to $7.63 \mathrm{ng} / \mathrm{g}$ dry wt., control (garden and greenhouse soil) topsoil where Ni was present in trace amounts. This proves that the root biomass of $Q$. ilex has the capacity for complexing $\mathrm{Ni}$. Cr exhibited the least adsorption values for all the three types of phytomass compared to other metals. The trend of adsorption of the phytomass was similar for Ni and Cd, i.e. root $>$ leaf $>$ stem. Desorption with $10 \mathrm{mM} \mathrm{Na}_{4}$ EDTA was effective (55-90\%) and, hence, there exists the possibility of recycling the phytomass. The biosorption results of recycled phytomass suggest that the selected adsorbents are re-usable. The advantages and potential of the $Q$. ilex phytomass as a biofilter of toxic trace metals, the scope and need for enhancing the efficiency of the $Q$. ilex phytomass as an adsorbent of metals are presented. (C) 2000 Elsevier Science Ltd. All rights reserved.
\end{abstract}

Keywords: Quercus ilex; Chromium; Nickel; Copper; Cadmium; Lead; Stem; Root; Phytomass; Biosorption; Desorption

\section{Introduction}

Heavy metals are released into the aqueous environment through a variety of sources such as metal smelters, effluents from plastics, textiles, microelectronics, wood preservatives-producing industries, usage of fertilizers and pesticides (Ross, 1994; Prasad and Hagemeyer, 1999). Natural waters also contain toxic metals depending upon the bed rock (Greger 1999).

The cost of decontamination of toxic metals from industrial effluents and wastewaters using ion exchange resins is exorbitant. Hence, that the usage of indigenous biodegradable resources for treating hazardous waste

\footnotetext{
* Corresponding author. Fax: +91-040-3010120/3010145.

E-mail address: mnvsl@uohyd.ernet.in (M.N.V. Prasad).

${ }^{1}$ Permanent address: Department of Plant Sciences, School of Life Sciences, University of Hyderabad, Hyderabad 500046, India.
}

would be less expensive is relevant to regional emerging environmental biotechnology. The concentration limits for classification of hazardous waste-containing metals vary for different metals (Table 1). To clean up metals in contaminated waters, a wide variety of biomass, including bacteria, fungi (free and immobilized), algae, and higher plants (agricultural and forestry wastes), have been tested as adsorbents (Table 2).

Quercus ilex L. (holly oak) is an evergreen tree which plays an important role in western Mediterranean ecosystems. It is the only tree growing in the serpentine area of about 8000 ha in northeast Portugal. The serpentine soils are very poor in essential nutrients and high in toxic metals such as chromium $(\mathrm{Cr})$, cobalt $(\mathrm{Co})$, nickel (Ni) (Sequeira and Pinto da Silva, 1991). In the urban area of Naples in Italy, $Q$. ilex has been used for trace metal biomonitoring in the soil environment (Alfani et al., 1996). Hence, Q. ilex phytomass (stem, 
Table 1

Concentration limit (international standards) of some metals for classification as hazardous waste (Balköse and Baltacioğlu, 1992)

\begin{tabular}{lc}
\hline Metal & Water $(\mathrm{mg} / \mathrm{l})$ or soil $(\mathrm{mg} / \mathrm{kg})$ \\
\hline $\mathrm{Cu}$ & 2.5 \\
$\mathrm{Zn}$ & 20 \\
$\mathrm{Ni}$ & 20 \\
$\mathrm{Cd}$ & 1 \\
$\mathrm{Hg}$ & 0.2 \\
\hline
\end{tabular}

leaf, root), which is widely available in southern Europe, was tested for its ability to adsorb selected metals, such as cadmium $(\mathrm{Cd}), \mathrm{Cr}$, copper $(\mathrm{Cu}), \mathrm{Ni}$, and lead $(\mathrm{Pb})$ from aqueous solutions.

\section{Materials and methods}

\subsection{Phytomass}

Q. ilex leaf, stem and root samples (3-year-old plants) were collected from the experimental plots located in the botanical garden, Department of Botany, University of Coimbra (Jardim Botânico, Departamento de Botânica, Universidade de Coimbra, Coimbra, Portugal). Samples were oven dried at $55^{\circ} \mathrm{C}$ overnight. Dried material was ground to homogenous powder using mortar and pestle with the help of liquid nitrogen

\subsection{Biosorption}

The homogenously powdered phytomass $1 \mathrm{~g}$ (particle size smaller than $200 \mu \mathrm{m}$ ) was added to $100 \mathrm{ml}$ containing $10 \mathrm{mg} / \mathrm{l}$ metal solution. The metal solutions $(\mathrm{Cr}, \mathrm{Ni}$, $\mathrm{Cu}, \mathrm{Cd}, \mathrm{Pb}$ ) were prepared by dilution of $1000 \mathrm{mg} / \mathrm{l}$ atomic absorption standard solutions procured from Reagecon, Ireland. The samples were stirred in separate beakers at room temperature $\left(22 \pm 2^{\circ} \mathrm{C}\right)$ for $1 \mathrm{~h}$. Addition of phytomass to metal ion-containing solution resulted in different initial $\mathrm{pH}\left(\mathrm{pH}_{\mathrm{i}}\right)$ after $1 \mathrm{~h}$. The $\mathrm{pH}$ was adjusted to facilitate adsorption with $0.1 \mathrm{~N} \mathrm{NaOH}$ or $0.1 \mathrm{~N} \mathrm{H}_{2} \mathrm{SO}_{4}$. During the experimentation of biosorption, the $\mathrm{pH}$ of the solutions was regularly monitored with a $\mathrm{pH}$ meter (Metrohm, 716 DMS Titrino, Switzerland). The experiment was continued for 3 days, and the final $\mathrm{pH}\left(\mathrm{pH}_{\mathrm{f}}\right)$ was recorded.

\subsection{Sedimentation}

Solutions containing metal ions and phytomass were stirred at regular intervals and allowed to settle. No cationic flocculants were used to facilitate sedimentation. The settled phytomass in metal ion-containing solutions could be observed by the naked eye. The clear supernatant was decanted into glass vials for analysis.

\subsection{Desorption and recycling}

After 3 days of biosorption, the clear supernatant was used for metal ion analysis and the phytomass was washed $(\times 3)$ with deionized water and oven dried overnight. The dried phytomass was resuspended in $100 \mathrm{ml}$ of $10 \mathrm{mM} \mathrm{Na}_{4}$ EDTA for $6 \mathrm{~h}$. The filtrate was analysed for determining the metal desorbed. Deionized water was used to wash the residue. The phytomass after one cycle was oven dried overnight. The same procedure stated previously for biosorption was followed to test the phytomass potential for re-use

\subsection{Metal analysis}

After 3 days of biosorption, the residual concentration of the metal ions was estimated by an atomic absorption spectrophotometer (Perkin Elmer AAnalyst 100). The experiment was repeated twice and results averaged. All glassware used was soaked in $10 \%$ nitric acid overnight and rinsed $(\times 3)$ with deionized water before allowing to dry. The results of heavy metals adsorbed to stem, leaf, and root phytomass were quantified by mass balance following Vázquez et al. (1994):

$R=\frac{C_{\mathrm{i}}-C_{\mathrm{r}}}{C_{\mathrm{i}}} \times 100$

$\frac{x}{m}=\frac{C_{\mathrm{i}}-C_{\mathrm{r}}}{m}$,

where $R$ is the percentage of metal adsorbed from initial concentration (i.e. $10 \mathrm{mg} / 1$ in all the experiments), $x / m$ is the mass of metal adsorbed/mass of the phytomass (stem, leaf, root) $(\mathrm{mg} / \mathrm{g}), m$ is the concentration of phytomass in the solution $(\mathrm{g} / \mathrm{l}), C_{\mathrm{i}}$ is the initial concentration of metal at the start of the biosorption $(\mathrm{mg} / \mathrm{l})$ and $C_{\mathrm{r}}$ is the residual concentration of the metal $(\mathrm{mg} / \mathrm{l})$ after 3 days of biosorption.

\section{Results}

Various samples of phytomass in contact with metalcontaining solution exhibited a wide range of $\mathrm{pH}$ values (Table 3) possibly due to the nature of the anions. To maximize the adsorption of the metals to phytomass, $\mathrm{pH}$ adjustment was performed. Initially, adsorption experiments conducted with $\mathrm{Ni}$ indicated that the $\mathrm{pH}$ and the duration of contact time of phytomass with aqueous solution were the important factors for the removal of metal having an initial concentration $10 \mathrm{mg} /$ 1. A value of $\mathrm{pH} 6$ gave optimum results over a period of $6 \mathrm{~h}$ (Fig. 1). The highest adsorption values were obtained after 3 days. Further, prolongation of contact time to 6 days did not increase adsorption (Fig. 2). On 
Table 2

Heavy metal removal and recovery from aqueous solutions using various kinds of biomass as adsorbent

\begin{tabular}{|c|c|c|}
\hline Metal(s) & Adsorbent & Reference \\
\hline \multirow[t]{7}{*}{ Variety of heavy metals } & Bark & Randall (1977); Randall et al. $(1974,1976)$ \\
\hline & Agrowaste & Kumar and Dara (1982) \\
\hline & Apple waste & Maranon and Sastre (1991) \\
\hline & Cellulose & Shukla and Sakhardande (1991) \\
\hline & Green algae & Roy et al. (1993) \\
\hline & Rice hulls & \\
\hline & Immobilized Aspergillus niger, A. oryzae & Kapoor and Viraraghavan (1998) \\
\hline $\mathrm{Ni}, \mathrm{Cu}, \mathrm{Zn}, \mathrm{Cd}, \mathrm{Hg}, \mathrm{Pb}$ & Wool fibers & Balköse and Baltacioğlu (1992) \\
\hline $\mathrm{Cd}, \mathrm{Cu}, \mathrm{Pb}, \mathrm{Ni}$ & Aspergillus niger & Kapoor and Viraraghavan (1998) \\
\hline $\mathrm{Cr}, \mathrm{Ni}, \mathrm{Pb}, \mathrm{Cd}, \mathrm{Zn}$ & Olive, Olea europea, mill waste & Gharaibeh et al. (1988) \\
\hline $\mathrm{Zn}, \mathrm{Cu}, \mathrm{Ni}$ & $\begin{array}{l}\text { Streptomyces rimosus (bacteria), Saccharomyces cerevisiae (yeast), } \\
\text { Penicillium chrysogenum (fungi), Fucus vesiculosus and } \\
\text { Ascophyllum nodosum (marine algae) }\end{array}$ & Bakkaloglu et al. (1998) \\
\hline $\mathrm{Pb}, \mathrm{Ni}, \mathrm{Cr}, \mathrm{Cd}, \mathrm{Cu}$ & Phanarochaete chrysosporium, $P$. versicolor & Yetis et al. (1998) \\
\hline $\mathrm{U}$ & Pinus radiata & Freer et al. (1989) \\
\hline \multirow[t]{2}{*}{$\mathrm{Hg}$} & Cotton & Roberts and Rowland (1973) \\
\hline & Coffee grounds & Macchi et al. (1986) \\
\hline \multirow[t]{5}{*}{$\mathrm{Cu}$} & Groundnut skins & Randall et al. (1975) \\
\hline & Immobilized Pseudomonas putida 5-X, Aspergillus niger & Chua et al. (1998) \\
\hline & & Townsley et al. (1986) \\
\hline & & Mullen et al. (1992) \\
\hline & Mucor rouxxi & Mullen et al. (1992) \\
\hline $\mathrm{Zn}, \mathrm{Cu}, \mathrm{Pb}$ & Pinus pinaster bark & Vázquez et al. (1994) \\
\hline \multirow[t]{5}{*}{$\mathrm{Cd}$} & Actinomycetes, Aspergillus niger A.oryzae & Kefala et al. (1999) \\
\hline & & Mullen et al. (1992) \\
\hline & & Kiff and Little (1986) \\
\hline & & Huang et al. (1988) \\
\hline & Rhizopus arrhizus, $R$. nigricans & Holan and Volesky (1995) \\
\hline $\mathrm{Pb}, \mathrm{Ni}$ & Marine algae & Holan and Volesky (1994) \\
\hline $\mathrm{Cr}(\mathrm{VI})$ & Rhizopus arrhizus & Prakasham et al. (1999) \\
\hline $\mathrm{Pb}$ & Rhizopus arrhizus, $R$. nigricans, Phanarochaete chrysogenum & Holan and Volesky (1995) \\
\hline $\mathrm{Ni}$ & Aspergillus niger, Rhizopus arrhizus & Holan and Volesky (1995) \\
\hline
\end{tabular}

the third day, the adsorption capacity of the different samples of phytomass was determined (Table 4). The metal adsorption capacity of the root for different metals was found to be in the order: $\mathrm{Ni}>\mathrm{Cd}>\mathrm{Pb}>$
$\mathrm{Cu}>\mathrm{Cr}$; stem $\mathrm{Ni}>\mathrm{Pb}>\mathrm{Cu}>\mathrm{Cd}>\mathrm{Cr}$; and leaf $\mathrm{Ni}>$ $\mathrm{Cd}>\mathrm{Cu}>\mathrm{Pb}>\mathrm{Cr}$. The highest amount adsorbed was $\mathrm{Ni}$ (root $>$ leaf $>$ stem). After determining the adsorption values, the solution was filtered and the phytomass 
Table 3

The $\mathrm{pH}$ values of various types of phytomass with different metal-containing aqueous solutions

\begin{tabular}{|c|c|c|c|c|c|c|}
\hline \multirow[t]{2}{*}{ Metal } & \multicolumn{3}{|c|}{$\mathrm{pH}_{\mathrm{i}}($ after $1 \mathrm{~h})$} & \multicolumn{3}{|c|}{$\mathrm{pH}_{\mathrm{f}}$ (after 3 days) } \\
\hline & Stem & Leaf & Root & Stem & Leaf & Root \\
\hline $\mathrm{Pb}$ & 2.67 & 2.67 & 2.64 & 5.2 & 6.1 & 6.0 \\
\hline $\mathrm{Ni}$ & 5.26 & 5.06 & 5.3 & 6.1 & 6.3 & 6.2 \\
\hline $\mathrm{Cd}$ & 2.67 & 2.63 & 2.58 & 7.0 & 6.8 & 6.5 \\
\hline $\mathrm{Cu}$ & 2.63 & 2.66 & 2.65 & 5.4 & 5.3 & 5.4 \\
\hline $\mathrm{Cr}$ & 2.71 & 2.62 & 2.6 & 5.0 & 4.8 & 5.4 \\
\hline
\end{tabular}

was oven dried and suspended in $100 \mathrm{ml}$ of $10 \mathrm{mM} \mathrm{Na}_{4}$ EDTA for $6 \mathrm{~h}$. The amount of metal desorbed by the phytomass is shown in Table 5. The results indicate that the phytomass is re-usable. The deficit in recovery could

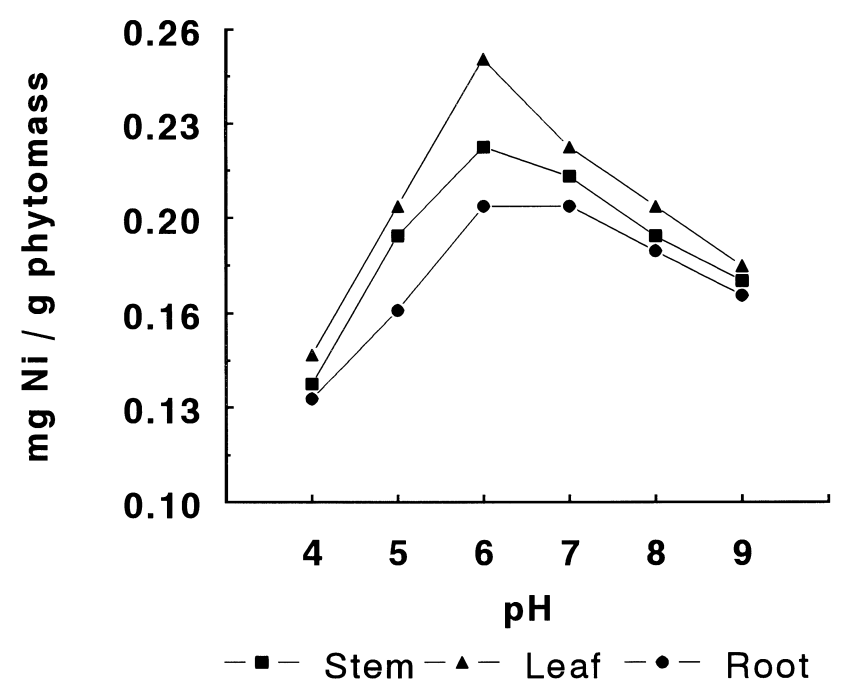

Fig. 1. Influence of $\mathrm{pH}$ on the removal of nickel (Ni) by the stem, leaf, and root phytomass of Quercus ilex. be partly due to the loss of the phytomass (via digestion) and variations in solution physico-chemistry.

\section{Discussion}

The principal metal-binding ligands reported in plant tissues encompass amino acids, oligo- and polypeptides (glutathione, phytochelatins, metallothioneins); macrocyclic agents (porphyrins, cobalamines, chlorophylls); polysaccharides and glycosides (rhamnogalacturonan); nucleobases, oligo-polynucleosides and nucleotides (DNA fragments) (Lobinski and Potin-Gautier, 1998). Several of these metal-binding bioligands were reported in the vascular tissues (xylem, phloem) of the plants. Most of the transitional and some main group metal ions form complexes with these bioligands (Prasad, 1998, 1999; Pohlmeier, 1999).

In an earlier investigation from this laboratory, Nabais et al. (1996) determined the Ni concentrations in the main stem of $Q$. ilex growing on serpentine and sandy loam soils. Nabais et al. (1997) quantified the amino acids and carboxylic acids in the xylem sap of $Q$. ilex and discussed their role in $\mathrm{Ni}$ binding and

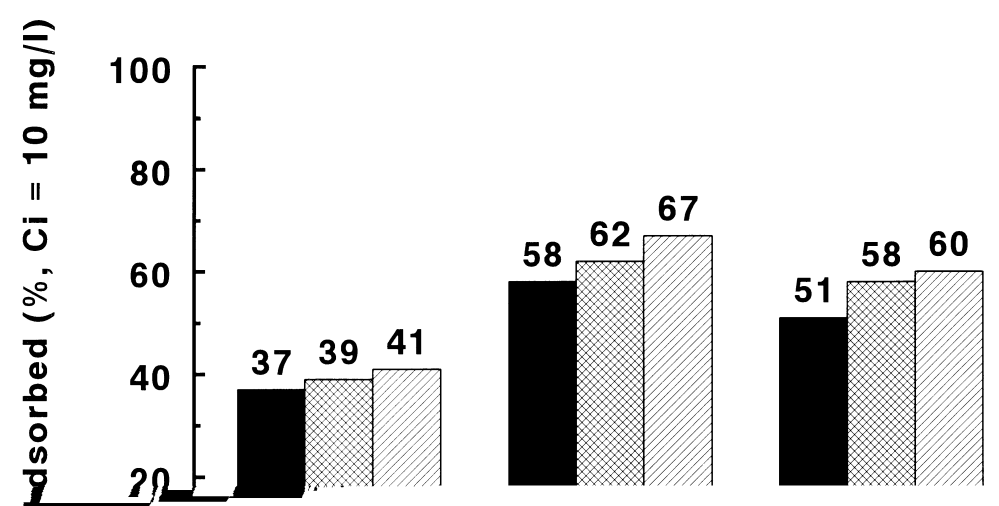

Fig. 2. Influence of contact time on the removal of nickel (Ni) by the stem, leaf, and root phytomass of Quercus ilex. 
Table 4

Comparison of biosorption of metal ions on various types of phytomass of Quercus ilex phytomass

\begin{tabular}{|c|c|c|c|c|c|}
\hline & \multicolumn{2}{|c|}{ Metal ion concentration } & \multirow[t]{2}{*}{ Biosorption efficiency (\%) } & \multicolumn{2}{|c|}{ Metal adsorbed } \\
\hline & Initial (mg/l) & Final (mg/l) & & $\mathrm{mg} / \mathrm{g}$ & $\mu \mathrm{mol} / \mathrm{g}$ \\
\hline \multicolumn{6}{|l|}{$P b$} \\
\hline Stem & 10 & 2.52 & 74.8 & 0.75 & 3.6 \\
\hline Leaf & 10 & 6.05 & 39.5 & 0.4 & 1.9 \\
\hline Root & 10 & 4.4 & 56.0 & 0.56 & 2.7 \\
\hline \multicolumn{6}{|l|}{$N i$} \\
\hline Stem & 10 & 4.2 & 58.0 & 0.58 & 9.9 \\
\hline Leaf & 10 & 3.83 & 62.0 & 0.62 & 10.6 \\
\hline Root & 10 & 0.62 & 67.2 & 0.67 & 11.5 \\
\hline \multicolumn{6}{|l|}{$C d$} \\
\hline Stem & 10 & 6.38 & 36.2 & 0.36 & 3.2 \\
\hline Leaf & 10 & 4.68 & 53.2 & 0.53 & 4.73 \\
\hline Root & 10 & 4.0 & 60.0 & 0.6 & 5.3 \\
\hline \multicolumn{6}{|l|}{$\mathrm{Cu}$} \\
\hline Stem & 10 & 7.88 & 21.2 & 0.21 & 3.3 \\
\hline Leaf & 10 & 8.0 & 20.0 & 0.20 & 3.14 \\
\hline Root & 10 & 8.81 & 11.9 & 0.12 & 1.87 \\
\hline \multicolumn{6}{|l|}{$\mathrm{Cr}$} \\
\hline Stem & 10 & 9.32 & 6.8 & 0.07 & 1.3 \\
\hline Leaf & 10 & 9.18 & 8.2 & 0.08 & 1.6 \\
\hline Root & 10 & 9.08 & 9.2 & 0.09 & 1.77 \\
\hline
\end{tabular}

Table 5

Desorption values and biosorption efficiency of recycled phytomass

\begin{tabular}{|c|c|c|c|c|c|c|}
\hline \multirow[t]{2}{*}{ Metal } & \multicolumn{3}{|c|}{ Percentage desorbed with $10 \mathrm{mM} \mathrm{Na}_{4}$ EDTA } & \multicolumn{3}{|c|}{ Biosorption efficiency (\%) of recycled phytomass } \\
\hline & Stem & Leaf & Root & Stem & Leaf & Root \\
\hline $\mathrm{Pb}$ & 78 & 65 & 69 & 65 & 27 & 35 \\
\hline $\mathrm{Ni}$ & 70 & 73 & 79 & 47 & 54 & 40 \\
\hline $\mathrm{Cd}$ & 63 & 55 & 67 & 28 & 40 & 35 \\
\hline $\mathrm{Cu}$ & 85 & 78 & 77 & 17 & 12 & 5 \\
\hline $\mathrm{Cr}$ & 82 & 85 & 90 & 2 & 6 & 8 \\
\hline
\end{tabular}

transport. The concentration of $\mathrm{Ni}$ in the xylem was as high as $5282.4 \mathrm{ng} / \mathrm{g}$ dry wt. in $Q$. ilex growing on serpentine soils as compared to $704 \mathrm{ng} / \mathrm{g}$ dry wt. in plants growing on sandy loam soils. This confirms that the phytomass of $Q$. ilex comprises Ni-binding and- transporting bioligands and would be of significance in phytoremediation of metal-contaminated soils and water (Prasad and Freitas, 1999).

Nabais and Freitas (Department of Botany, University of Coimbra, Coimbra, unpublished data) also developed a functional model for $\mathrm{Ni}$ transport and complexation in $Q$. ilex trees based on field and experimental data. Branches of $Q$. ilex growing on serpentine and sandy loam soils of northeast Portugal were collected every month for 1 year and the Ni concentrations in the xylem sap, leaves, xylem and phloem tissues were analyzed.
The average concentrations were:

$\begin{array}{ll}\begin{array}{l}\text { Serpentine soils } \\ \text { (ng/g dry wt.) }\end{array} & \begin{array}{l}\text { Sandy loam } \\ \text { (ng/g dry wt.) }\end{array} \\ 23.5 & 16 \\ 24.5 & 18.3 \\ 17.8 & 16\end{array}$

Nabais and Freitas (Department of Botany, University of Coimbra, Coimbra, unpublished data) also performed another experiment using 1-year-old $Q$. ilex trees growing in soil artificially contaminated with 500 , 1000 , or $2000 \mathrm{mg} / 1$ of total $\mathrm{Ni}$. This experiment substantiated that $\mathrm{Ni}$ is mostly sequestered in the roots where concentrations can be as high as $428.4 \mathrm{ng} / \mathrm{g}$ dry wt., in the $2000 \mathrm{mg} / 1$ treatment, compared to $7.6 \mathrm{ng} / \mathrm{g}$ 
dry wt., in the control. Xylem transport of $\mathrm{Ni}$ to the leaves was low. Leaves from the $2000 \mathrm{mg} / \mathrm{l}$ treatment showed an average concentration of Ni of $32.8 \mathrm{ng} / \mathrm{g}$ dry wt., compared to $11.2 \mathrm{ng} / \mathrm{g}$ dry wt. in the control, supporting Ni accumulation in leaves several times that in the control trees (Freitas, 1999).

$Q$. ilex phytomass is abundantly available in northeast Portugal. Different parts of the plant have different adsorption abilities due to localization of specific ligands which have an affinity to bind a particular metal (Table 4). For enhancing the ability of metal adsorption, chemical pretreatment might be helpful and would expose the metal-binding ligands in the chosen tissues (Vázquez et al., 1994). Physico-chemical parameters, such as temperature, $\mathrm{pH}$ of the contact solution and conditions of the reaction, e.g. continuous or batch mode, are reported to influence the adsorption results (Balköse and Baltacioğlu, 1992; Vázquez et al., 1994). The distribution coefficient of $\mathrm{Ni}, \mathrm{Cu}, \mathrm{Zn}, \mathrm{Cd}, \mathrm{Hg}$ and $\mathrm{Pb}$ was dependent on temperature when wool fibers were used as adsorbent. At $50^{\circ} \mathrm{C} \mathrm{Cu}, \mathrm{Zn}$ and $\mathrm{Pb}$ had higher values, whereas for $\mathrm{Ni}, \mathrm{Cd}$, and mercury $(\mathrm{Hg})$ the distribution coefficient values were higher at $25^{\circ} \mathrm{C}$ (Balköse and Baltacioğlu, 1992). Hence, standardization of physico-chemical parameters and experimental conditions might be useful to optimize the efficacy of the chosen adsorbent.

\section{Conclusions}

This work, for the first time, emphasizes the potential of the $Q$. ilex phytomass as an adsorbent of toxic metal ions from solution. The $Q$. ilex phytomass is abundantly available and, hence, methodology based on its usage as adsorbent would be inexpensive, unlike some fungal-, algal- and microbial biomass-based reactors which require expensive culture media, and costly biosafety precautions. Further, the biosorption potential of $Q$. ilex root phytomass for $\mathrm{Ni}$ is quite promising. Utilization of $Q$. ilex phytomass and its relevance to metal chelation has tremendous scope for developing and designing innovative clean-up technologies. Accordingly, supplementary experimentation is being planned with $Q$. ilex aiming at the removal and recovery of toxic metal ions not only in natural and industrial wastewaters but also in metal-contaminated soils.

\section{Acknowledgements}

M.N.V.P. is grateful to the Fundação para a Ciência e a Tecnologia, Ministério da Ciencia e Tecnologia, Portugal, for financial assistance (December 1998 to February 1999). The authors are extremely thankful to the anonymous referee for critical comments on this manuscript. Thanks are due to Ms. Cristina Nabais and $\mathrm{Mr}$ António do Carmo Gouveia for help in atomic absorption analyses.

\section{References}

Alfani, A., Bartoli, G., Rutigliano, F.A., Maisto, G., De Santo, A.V., 1996. Trace metal biomonitoring in the soil and the leaves of Quercus ilex in the urban area of Naples. Biological Trace Element Research 51, 117-131.

Bakkaloglu, I., Butter, T.J., Evison, L.M., Holland, F.S., Hancock, I.C., 1998. Screening of various types of biomass for removal and recovery of heavy metals $(\mathrm{Zn}, \mathrm{Cu}, \mathrm{Ni})$ by biosorption, sedimentation and desorption. Water Science and Technology 38, 269-277.

Balköse, D., Baltacioğlu, H., 1992. A desorption of heavy metal cations from aqueous solutions by wool fibers. Journal of Chemical Technology and Biotechnology 54, 393-397.

Chua, H., Wong, P.K., Yu, P.H.F., Li, X.Z., 1998. The removal and recovery of copper ions(II) from wastewater by magnetite immobilized cells of Pseudomonas putida 5-X. Water Science and Technology $38,315-322$.

Freer, J., Baeza, J., Maturana, H., Palma, G., 1989. Removal and recovery of uranium by modified Pinus radiata D.Don bark. Journal of Chemical Technology and Biotechnology 46, 41-48.

Freitas, H., 1999. Binding of metal ions in the xylem of trees (Quercus ilex). Abstract No. 11.10.3. 16th Int. Bot. Congr. St. Louis, MO, USA. 1-7 August.

Gharaibeh, S.H., Abu-El-Shar, W.Y., Al-Kofahi, M.M., 1998. Removal of selected heavy metals from aqueous solutions using processed solid residue of olive mill products. Water Research 32, 498-502.

Greger, M., 1999. Metal availability and bioconcentration in plants. In: Prasad, M.N.V., Hagemeyer, J. (Eds.), Heavy Metal Stress in Plants: From Molecules to Ecosystems. Springer, Berlin, pp. 1-28.

Holan, Z.R., Volesky, B., 1994. Biosorption of lead and nickel by biomass of marine algae. Biotechnology and Bioengineering 43, 1001-1009.

Holan, Z.R., Volesky, B., 1995. Accumulation of cadmium, lead, nickel by fungal and wood biosorbents. Applied Biochemistry and Biotechnology 53, 133-146.

Huang, C.P., Westman, D., Quirk, K., Huang, C.P., Morehart, A.L., 1988. Removal of cadmium (II) from dilute solutions by fungal biomass. Science and Technology 6, 405-419.

Kapoor, A., Viraraghavan, T., 1998. Removal of heavy metals from aqueous solutions using immobilized fungal biomass in continuous mode. Water Research 32, 1968-1977.

Kefala, M.I., Zouboulis, A.I., Matis, K.A., 1999. Biosorption of cadmium ions by Actinomycetes and separation by flotation. Environmental Pollution 104, 283-293.

Kiff, R., Little, D.R., 1986. Biosorption of heavy metals by immobilized fungal biomass. In: Eccles, H., Hunt, S. (Eds.), Immobilization of Ions by Biosorption. Ellis Horwood, Chichester, pp. 71-80.

Kumar, P., Dara, S.S., 1982. Utilization of agricultural wastes for decontaminating industrial/domestic wastewaters from toxic metals. Agriculture Wastes 4, 213-223.

Lobinski, R., Potin-Gautier, M., 1998. Metals and biomolecules bioinorganic analytical chemistry. Analusis 26, 21-24.

Macchi, G., Marani, D., Tirivanthi, G., 1986. Uptake of mercury by exhausted coffee grounds. Environmental Technology Letters 7, 431-444.

Maranon, E., Sastre, H., 1991. Heavy metal removal in packed beds using apple waste. Bioresource Technology 38, 39-43.

Mullen, M.D., Wolf, D.C., Beveridge, T.J., Bailey, G.W., 1992. Sorption of heavy metals by soil fungi Aspergillus niger and Mucor rouxxi. Soil Biology and Biochemistry 24, 129-135. 
Nabais, C., Freitas, H., Hagemeyer, J., Breckle, S.W., 1996. Radial distribution of $\mathrm{Ni}$ in stem wood of Quercus ilex $\mathrm{L}$. trees growing on serpentine and sandy loam (umbric leptosol) soils of NE-Portugal. Plant Soil 183, 181-185.

Nabais, C., Freitas, H., Hagemeyer, J. 1997. Seasonal variation of amino acids and organic acids in the xylem sap of Quercus ilex L. growing on serpentine and sandy loam soils. In: Ando, T. et al. (Eds.), Plant Nutrition for Sustainable Food Production and Environment. Kluwer Academic, Japan, pp. 405-406.

Pohlmeier, A., 1999. Metal speciation, chelation and complexing ligands in plants. In: Prasad, M.N.V., Hagemeyer, J. (Eds.), Heavy Metal Stress in Plants: From Molecules to Ecosystems. Springer, Berlin, pp. 29-50.

Prasad, M.N.V., 1998. Metal-biomolecule complexes in plants: occurrence, functions and applications. Analusis 26, 25-28.

Prasad, M.N.V., 1999. Metallothioneins and metal binding complexes in plants. In: Prasad, M.N.V., Hagemeyer, J. (Eds.), Heavy Metal Stress in Plants: From Molecules to Ecosystems. Springer, Berlin, pp. 51-72.

Prasad, M.N.V., Freitas, H., 1999. Feasible biotechnological and bioremediation strategies for serpentine soils and mine spoils. Electronic Journal of Biotechnology 2, 36-50. Online Journal at website: http://ejb.ucv.cl or http://ejb.org.

Prasad, M.N.V., Hagemeyer, J., 1999. Heavy Metal Stress in Plants From Molecules to Ecosystems. Springer, Berlin.

Prakasham, R.S., Merrie, J.S., Sheela, R., Saswathi, N., Ramakrishna, S.V., 1999. Biosorption of chromium VI by free and immobilized Rhizopus arrhizus. Environmental Pollution 104, 421-427.

Randall, J.M., 1977. Variations in effectiveness of bark as scavengers for heavy metal ions. Forest Production Journal 27, 51-56.

Randall, J.M., Garret, V., Bermann, R.L., Waiss, A.C., 1974. Use of bark to remove heavy metal ions from waste solutions. Forest Production Journal 24, 80-84.
Randall, J.M., Reuter, F.W., Waiss, A.C., 1975. Removal of cupric ions from solution by contact with peanut skins. Journal of Applied Polymer Science 19, 1563-1571.

Randall, J.M., Hautala, E., Waiss, A.C., Tschernitz, J.L., 1976. Modified barks as scavengers for heavy metal ions. Forest Production Journal 26, 46-50.

Roberts, E.J., Rowland, S.P., 1973. Removal of mercury from aqueous solutions by nitrogen containing chemically modified cotton. Environmental Science and Technology 7, 552-555.

Ross, S.M., 1994. Toxic Metals in Soil Plant Systems. Wiley, Chichester, UK.

Roy, D., Greenlaw, P.N., Shane, B.S., 1993. Adsorption of heavy metals by green algae and ground rice hulls. Journal of Environmental Science and Health Part A 28, 37-50.

Sequeira, E.M.D., Pinto da Silva, A.R., 1991. The ecology of serpentinized areas of northeast Portugal. In: Roberts, B.A., Proctor, J. (Eds.), The Ecology of Areas with Serpentinized Rocks. A World Review. Kluwer Academic Publishers, Dordrecht, pp. 169-197.

Shukla, S.R., Sakhardande, V.D., 1991. Metal ion removal by dyed cellulosic materials. Journal of Applied Polymer Science 42, 829832.

Townsley, C.C., Ross, I.S., Atkins, A.S., 1986. Copper removal from a simulated leach effluent using filamentous fungus Trichoderma virdie. In: Eccles, H., Hunt, S. (Eds.), Immobilization of Ions by Biosorption. Ellis Horwood, Chichester, pp. 159-170.

Vázquez, G., Antorrena, G., González, J., Doval, M.D., 1994. Adsorption of heavy metals ions by chemically modified Pinus pinaster bark. Bioresource Technology 48, 251-255.

Yetis, U., Ozcengiz, G., Dilek, F.B., Ergen, N., Erbay, N., Dolek, A., 1998. Heavy metal biosorption by white-rot fungi. Water Science and Technology 38, 323-330. 